\title{
Kamuda İşletmecilik Eksenli Değişimle Birlikte Çalışanlarda Örgütsel Bağlılık Ve İş Tatmini Düzeyleri: PTT Üzerine Bir Alan Araştırması
}

\author{
Osman Kürşat ACAR ${ }^{1}$ Çağdaş TÜRKOĞLU ${ }^{2}$ \\ ${ }^{1}$ Süleyman Demirel Üniversitesi İktisadi ve İdari Bilimler Fakültesi, İnsan Kaynakları Yönetimi Isparta \\ ${ }^{2}$ Süleyman Demirel Üniversitesi Sosyal Bilimler Enstitüsü, Isparta
}

\begin{abstract}
Özet
İşletme bilimi alanında, üzerinde çok fazla araştırma yapılan konulardan olan iş tatmini ve örgütsel bağlllık konusu son dönemlerde kamu kurumlarında da araştırılmaya başlanmıştır. Türk kamu yönetiminde,1980 sonrası özel sektör yöntem ve tekniklerinin etkili olduğu işletmecilik eksenli yeni kamu yönetimi anlayışı etkili olmaya başlamıştır. İktisadi bir kamu yönetim kuruluşu olan PTT A.Ş. 'de yapısı itibariyle bu değişimden etkilenmiş ve çalışanların iş yükleri ciddi oranlarda artmıştır. Bu çalışma kapsamında PTT AŞ'de çalışanlarının yeni kamu yönetimi anlayışı ile birlikte yaşanan, işletmecilik eksenli değişimin örgütsel bağllık ve iş tatmin düzeylerine olan etkisi ölçülmüștür. Çalışma sonucunda beklenilenin aksine çalışanların iş yüklerinin artması sonucunda iş tatmini ve örgütsel bağlılıklarının düşmesi yönünde bulgulara rastlanmamıştır.
\end{abstract}

Anahtar Kelimeler: Yeni Kamu Yönetimi, İş Tatmini, Örgütsel Bağlılık, PTT A.Ş.

\section{Organizational Commitment and Job Satisfaction Levels in Employees Working in the Public} Business with Axis Shift: A Field Study on PTT

\begin{abstract}
Job satisfaction and organizational commitment, which is the subject of much research in the field of business science, have recently begun to be investigated in public institutions. After 1980 in Turkish public administration, new business oriented public management understanding, which is affected by private sector methods and techniques has come to the forefront. PTT Inc., an economic public administration body, was structurally affected by this change and the workload of employees has increased dramatically. In this study, the effect of business oriented change with the new public management understanding in PTT Inc. on employees' organizational commitment and job satisfaction levels has been measured. As a result of the study, contrary to expectations, increased workload of employees does not reduce job satisfaction and organizational commitment.
\end{abstract}

Keywords: New Public Management, Job Saticfaction and Organizational Commitment, PTT Inc.

\section{Giris}

Çalışanların örgütteki ortamlarına karşı reaksiyonlarını ifade eden iş tatmini ile çalışanların örgüt ile özdeşleşerek; örgütün ilke, amaç ve değerlerini benimsemesinin, kurumsal kazançlar için çaba göstermesinin ve örgütte çalışmayı sürdürme isteğinin ölçüsü olarak tanımlanan örgütsel bağlılık kavramı birbiri ile ilişkili kavramlardır (Kök, 2006: 292) İster kamu sektörü ister özel sektör olsun örgütlerin etkin ve verimli işgücüne olan taleplerinin arttığı günümüz şartlarında birçok örgütte çalışanların iş tatmini ve örgütsel bağlılıklarının düşük düzeyde olduğunu gösteren çalışmalar mevcuttur. PTT A.Ş. de bu yönde bir sorgulamaya ihtiyaç duyan bir kurum olarak örnek gösterilebilir.

1980’lerden itibaren kamu sektörünün de işletme mantığ ile yönetilmeye başlanması ve kamu yönetiminin işletme alanına kayması ile "yeni kamu işletmeciliğì" ve "yeni kamu yönetimi”" kavramları ortaya çıkmıştır. Son gelişmeler 1şığında kamu yönetimi ile işletme yönetiminin birleşme yönünde ilerlediğinin (Aydın, 2011: 29) ve hatta yeni sağ politikalarla kamu yönetim anlayışının değişime zorlanarak, kamu yönetimi yerine kamu işletmeciliği anlayışının ikame edilmesi gerektiği yönünde görüşler ileri sürülmeye başlanmıştır (Üstüner, 1994). Özetle kamu yönetiminde işletmecilik anlayışının hâkim olduğu bir paradigma değişiminden bahsedilmeye başlanmıştır.

Paradigması değişen Türk kamu yönetiminde idari, iktisadi, bilimsel ve sosyal kamu hizmeti sunan kurumlar bulunmaktadır. Bunlardan Milli Güvenlik Kurulu Genel
Sekreterliği idari kuruma, Gebze İleri Teknoloji Enstitüsü bilimsel hizmet sunan kuruma, Türkiye Cumhuriyeti Devlet Demir Yolları iktisadi alana ve Yüksek Öğrenim Kredi ve Yurtlar Kurumu Genel Müdürlüğü sosyal kamu hizmeti sunan kuruma örnek olarak verilebilir.

Yap1 incelendiğinde yeni kamu yönetimi eksenli işletmecilik anlayışının uygulanabileceği kurumların öncelikli olarak iktisadi kamu kurumları olduğu görülmektedir. İşletmecilik eksenli değişime açık, iktisadi bir kamu işletmesi olan PTT A.Ş. irdelendiğinde süreç içerisinde hem iş hacminin arttığı hem de örgütsel değişimlere uğradı̆̆ 1 açıkça görülmektedir. Bu bağlamda, son dönemde PTT'nin de yeni kamu yönetimi eksenli değișim ile artan iş hacminin, PTT personeli üzerindeki etkisi ve dolaylı olarak iş tatmini ile örgütsel bağlılık arasındaki ilişkinin ne yönde değiştiğinin tespiti önemlilik arz etmektedir.

\section{Genel Olarak İş Tatmini ve Örgütsel Bağllık Kavramları}

İş tatmini ve örgütsel bağlılık konuları, örgütsel davranıs alanında üzerinde en çok araştırma yapılan konular arasındadır. Bu konuda bankacılık sektöründen (Emhan ve Gök, 2011) yüzme hakemliğine kadar (Yıldırım vd, 2011) geniş yelpazede birçok sektörde iş tatmini ve örgütsel bağlılık konuları ölçülmeye çalışılmıştır. Disiplinlerarası çalışma şeklinde de karşımıza çıkan örgütsel bağlılık ve iş tatmini konuları, kamu örgütleri üzerinde de araştırma konusu olmuştur. Bu kavramlardan iş tatmini; bireyin çalışma yaşamı veya çalıştığı örgüt şartları arasındaki uyumun bir sonucu 
olarak ortaya çıkan memnuniyet duygusu ve bireyin işine karşı almış olduğu olumlu yönde bir davranış olarak tanımlanmaktadır (Ugboro ve Obeng, 2000: 254). Benzer şekilde, iş tatmini, bireyin mesleğe yönelik değerlerinin karşılığını veren ve mesleki takdirden dolayı oluşan pozitif duygusal bir davranış olarak da tanımlanmıştır (Moorhead, Griffin, 1996: 126). Bir başka bakış açısıyla iş tatmini bireylerin yaptığı işe yönelik inanç, bilgi, duygu, davranış ve değerlendirmelerini kapsayan tutumları içermektedir. Kişinin işine karşı edindiği deneyimler sonucu oluşan tutumu olumlu ise iş tatmini pozitif, kişinin işine karşı tutumu olumsuz ise iş tatmini de olumsuz olacaktır (Konuk, 2006: 59).

Çalışanların iş tatmin seviyelerinin yüksek olması örgütte verimliliği ve örgüte bağlılığı arttırmanın yanında işgücü devir hızını ve işe devamsızlıkları da düşürmektedir. Bu durumda örgütlerin arzuladığı hedefler daha ulaşılabilir hale gelmektedir (Tengilimoğlu, 2005: 27). Çalışanların işine karşı hissettiği tutumların bir sonucu olarak oluşan iş tatminini etkileyen birtakım faktörler vardır. Ücret, örgüt içinde yükselme firsatları, işin doğası ve niteliği muhtemel ödüller, yöneticiler, ek imkânlar, işleyiş prosedürleri, iş arkadaşları, iletişim, örgütün politika ve prosedürleri, çalışma şartları tutumların şekillenmesini kapsayan örgütsel faktörler ile kültürel ve çevre faktörleri bu faktörler arasında yer almaktadır (Aşan, Erenler, 2008:206, Örücü vd., 2006: 2-3; Duman, 2000: 14-15).

Bireyin çalıştığı örgüt ile kurmuş olduğu kuvvetli kimlik birliğinin ve kendisini örgütün bir parçası olarak hissetmesinin derecesi olarak tanımlanan örgütsel bağlılık kavramı (Schermerhorn vd., 1996: 44) kişinin kurumsal amaç ve değerleri kabul etmesine, bu amaçlara ulaşılması yönünde çaba sarf etmesine ve örgüt üyeliğini devam ettirme arzusunun artması anlamına gelmektedir (Swailes, 2002: 159). Bu alanda literatürde en çok başvurulan kişilerden olan Allen ve Meyer (1990: 4)'a göre örgütsel bağl1lık; duygusal bağl1lık, devam bağl1lığ 1 ve normatif bağl1lık olarak üç şekilde ortaya çıkmaktadır (Allen ve Meyer, 1990: 4). Bunlardan duygusal bağlılık çalışanların duygusal olarak örgüte olan eğilimini, örgütle birlikte tanımlamayı ve örgütle uyum sağlamayı anlatırken; devam bağlılığı örgütten ayrılma durumunda ortaya çıkacak maliyet algılarını ve son olarak normatif bağlılık da yönetime ve çalışma arkadaşlarına karşı çalışanın görev algılarını ifade etmektedir (Erdem, 2007: 67). Örgütsel bağlılık ile iş tatmini arasında bir korelasyon söz konusudur. Örgütsel bağlılık iş tatminini pozitif yönde etkilerken, iş tatmini de örgütsel bağlılığı aynı yönde etkilemektedir (Poyraz ve Kama, 2008 :143). Bu konuda hem kamu (Karataş ve Güleş, 2010 :74 ) hem de özel sektörde (Toker, 2007: 92) yapılan birçok çalışma ile bu ilişki ortaya konulmuş ve örgütsel bağlılığın yüksek olması durumunda çalışanların performansını, iş tatminini, örgütsel verimliliği attırdığ 1 ; işe devamsızlığı, personel devir hızını azalttığı sonuçlarına ulaşıldığı görülmektedir (Erdem, 2007: 67).

Bugün hızla değișmekte olan çevre şartları, ilerleyen rekabet koşulları, sürekli değişen kişisel ihtiyaçlar gibi sebeplerle özellikle nitelikli elamanlar başta olmak üzere çalışanları örgütte tutmak zorlaşmaktadır. Eğitimli ve uzman işgücü ihtiyacının artması ve bu nitelikle işgücü arzındaki yetersizlikler de konuyu daha önemli hale getirmektedir. İster kamuda ister özel sektörde olsun bir çalışanın yetiştikten ve iş yerine uyum sağlamasından sonra işten ayrılması örgütte yüksek maliyetlere sebep olmaktadır. Bu yüzden çalışanların örgütte kalma isteğini devam ettirmesinde, örgüt yönetimine ve faaliyetlerine katılmalarında, örgüt için yenilikçi bir tavır sergilemelerinde ve çalışanların örgüt amaçlarını benimsemesinde örgütsel bağlılık günümüz koşullarında çok önemli hale gelmiştir (Durna ve Eren, 2005: 211). İşletme yöneticilerinin, çalışanların örgütte kalma isteğine sahip olmalarının ve verimlilik artışının iş tatmini ve örgüte bağlı olmalarına yönelik olduğunun bilincinde olmaları gerektiği gibi (Çekmecelioğlu, 2006) kamu yöneticilerinin de yeni kamu yönetimi anlayışının da etkisiyle daha iyi kamu hizmeti sunmak için iş tatmini ve örgütsel bağlılık konularına önem vermeleri gerekmektedir.

Verilen bu bilgiler ışı̆̆ında konuya derinlik kazandırmak adına çalışmanın daha iyi algılanılabilmesi için kamu yönetiminde işletmecilik eksenli değişimin temeli olan Yeni Kamu Yönetimi anlayışı açıklanacaktır.

\section{Kamu Yönetiminde İșletmecilik Eksenli Değișim "Yeni Kamu Yönetimi”}

Türk kamu yönetimi, 1980'li y1llarda küreselleşmeyle birlikte dünyadaki gelişmelere paralel olarak bir değişim ihtiyacı içine girmiştir. 1980'lerle birlikte refah devleti sonucu oluşan ekonomik krizler, bütçe açıkları, hantal ve aşırı bürokratik devlet anlayıșı küreselleșme ve bilișim teknolojilerindeki gelişmeler ışı̆̆ında kamu yönetimlerinin girdiği krizden çıkabilmeleri için birtakım arayışlar başlamıştır (Çiçek, 2012: 65). Refah devletinden sosyal hizmetlere yönelik taleplerin artmasına paralel ortaya çıan mali krizler, ekonomiyi geliştirmek için en uygun kurum ve tekniklerin araştırılması, hantal, bürokratik, zorlayıcı idari yapılar içinde etkin ve verimli bir kamu yönetim anlayışına (Ömürgönülşen; 1997: 517) cevap olarak ve geleneksel kamu yönetimi anlayıșı yerine yeni bir kamu yönetimi anlayışı ileri sürülmüştür.

İleri sürülen "Yeni Kamu Yönetimi” kavramı, 1980’lerden bu yana batılı hükümetlerin ve/veya kamu kurumlarının verim ve performansını geliştirmeye yönelik bir dizi reforma birçok akademisyen tarafindan takılan genel isimlendirme olarak açıklanabilir. Türkiye kamu yönetim anlayışını dünyadaki gelişmelere paralel olarak yeni kamu yönetimi eksenli değiştirme yönünde adımlar atmıştır. Yeni kamu yönetimi anlayışına dönük gelişmeler öncelikle 1980’ler sonrasında teorik alanda kendini göstermiştir. Uygulamaya dönük olarak 2000 sonrasında geleneksel yönetim anlayışı yerine etkinlik, verimlilik, hesap verebilirlik, şeffaflık, sonuç odaklılık, performans yönetimi, müşteri memnuniyeti, kalite, rekabet fonksiyonel uzmanlaşma, özel sektör hizmet sunma yöntemlerinin kullanılması, kaynak kullanımında disiplin tasarrufa yönelme gibi ilke ve unsurlara dayalı "yeni kamu yönetimi” anlayışına doğru bir geçiş benimsenmiştir. Özellikle 2000 sonrası Türkiye'de gerçekleştirilen kamu yönetimi çıktılarının birçoğunda yeni kamu yönetim anlayışının izlerini görmek mümkündür (Lamba, 2014:147).

Özet olarak 1980 sonrası dönemde, kamu yönetiminin yapı ve işleyişi üzerine yapılan eleştirilerle iletişim ve teknolojideki yeniliklerle birlikte özel sektörde görülen değişim ve bundan dolayı ekonomik anlayışta kurallara uygun olarak işleri sevk ve idare etmek demek olan yönetim (administration) anlayışından; performans ölçme, sorumluluk alma, kaynakları etkin ve verimli kullanma, hedef, strateji ve öncelikleri belirleme demek olan işletme (management) anlayışına doğru 
bir kayma yaşanmıştır (Bilgiç, 2003: 32). Bu değişimle kamu yönetiminin piyasa yönelimli, daha az bürokratik, esnek, adem-i merkeziyetçi, girişimci ve yenilikçi olmayı destekleyen anlayışla daha etkin ve verimli olacağı iddia edilmiştir (Ömürgönülșen, 2013: 4-17).

$\mathrm{Bu}$ noktadan hareketle yeni kamu yönetimi anlayıșının etkili olduğu kurumlardan biri olan PTT A.Ş. personellerinin iş tatmini ve örgütsel bağl1lık düzeyleri incelenecektir.

\section{Yeni Kamu Yönetim Sonrası PTT A.Ş.’’de İş Tatmini ve Örgütsel Bağlılık}

Kamu yönetiminde işletmecilik eksenli yaşanan değişimin somut çıktılarına PTT A.Ş üzerinden bakıldığında, PTT A.Ş.'nin iş hacminin arttığı yapısı ve uygulamalarının süreç içerisinde değiştiği görülmektedir. Örneğin 2000 yılında 40.141 kişi ile y1llık 2 milyon adet iş yapılırken 2013 yılında 39.000 kişi ile yıllık 24 milyon adet işlem yapılmıştır. Eskiden kişi baş1 yıllık ortalama 50 işlem yapılırken bu rakam 2013 yılında kişi başı ortalama 615 gibi bir rakama çıkmıştır (Acar, 2013: 194).

Küreselleşmenin bir sonucu olarak rekabetin giderek yoğunluk kazandığı bir ortamda işletmelerin ayakta kalabilmeleri, işletme yönetimlerinin çalışanların işle ilgili tutum ve davranışlarını doğru ve sağlıklı bir biçimde yönetebilmelerine bağlı bulunmaktadır. $\mathrm{Bu}$ tutum ve davranışların en önemlileri iş tatmini, işten ayrılma niyeti, iş stresi, örgütsel bağlılık ve performanstır (Gül, vd., 2008: 7). $\mathrm{Bu}$ durum yeni kamu yönetimi anlayışı ile birlikte artık kamu sektörü için de geçerlidir. Kamuda veya özel sektörde malı ya da hizmeti üreten çalışanların verimlilikleri genellikle niceliğine bakılarak değerlendirilirken; insan olmaktan doğan hakları ve psikolojileri genellikle bu değerlendirmenin dışında tutulabilmektedir. Bu bağlamda, örgütsel bağlılığı sağlamak adına yapılan faaliyetlerin salt verimi artırma gayesi ile değil; aynı zamanda yaşamının büyük bir kısmını o örgütte geçiren insanların kişilik, değer, inanç ve yargılarını da hesaba katan bir yaklaşımla yapılması, çalışanların çalıştığı örgüte ve ait olduğu topumla büyük katkılar sağlayabilecektir (Bayram, 2005:137).

Türk kamu yönetiminde işletmecilik eksenli yaşanan bu değişimler sonucu PTT çalışanlarının iş tatmini ve örgütsel bağl1lık seviyelerinin eskiye oranla düştüğü ve benzer biçimde daha az personelle çalışma, piyasa metotlarının kamuda kullanılması sonucunda mobing vb. vakaların arttığına dair çeşitli çalışmalar yapılmıştır. $\quad$ PTT çalışanlarında moral ve motivasyon eksikliği, yıllık izinlerin kullanılamaması, personel eksikliği, eğitim eksikliği, merkezlerdeki güvenlik eksikliği PTT'de mevcut personelin efektif kullanılmaması, takım çalışmasının yetersizliği, iletişim araçlarının iyi şekilde kullanılmaması, merkezlerde danışma hizmetinin olmaması, doğru elamanın doğru yerde çalıştırılmaması, hizmet sunum standardının talebin yoğunluğuna göre dengeli olmaması, sosyal aktivite eksikliği, kurumun imajı, tanıtım eksikliği, müşteriye karşı gereksiz formaliteler, reklam eksikliği, organizasyon hataları, yaşlı personel fazlalığı, rotasyon olmaması gibi birçok problem mevcuttur (Arslan, 2012b: 251).

Yukarıda sayılan bu problemler ile PTT A.Ş'nin yeni kamu yönetimi eksenli girdiği dönüşüm arasında bir ilişki kurmak mümkün olabilir mi sorusudna yapılan çalışmalar bu ilişkiyi doğrulamaktadır. Yeni kamu yönetimi eksenli dönüşümün
PTT A.Ş. üzerindeki uygulamaların iş barışını bozduğu, çalışanların motivasyonunu, iş tatmini ve örgütsel bağlığ 1 düzeyini düşürdüğü yönünde değerlendirmeler mevcuttur (Acar, 2013: 194). Nitekim Arslan (2012b: 251)'1n Sakarya PTT Başmüdürlüğü çalışanlarının katkısı ve sosyolojik bakış açısıyla beşerî-sosyal sermayenin uygun kullanımının kurumsal verimlilik ve performansa etkisini ölçmeye yönelik çalışma sonuçları da bu bulguyu destekler niteliktedir. Yapılan çalışma sonuçlarına göre insana değer veren, insan ilişkilerini önemseyen ve bu durumu sürekli olumlu taraftan destekleyen süreçler, kuruluşlara yönelik başarı ve örgütsel ilerleme adına oldukça önemlidir ve bu boyut, kuruluşların yaşam süresini uzatan, verimlilik ve performansını güçlendiren bir boyut olarak karşımıza çıkmaktadır. İnsanları bir robot olarak görmeyip; etkileşim ve iletişim ile harekete geçirmeli ve artı bir değer yaratılarak katılımları sağlanmalı ve fikirlerinin alınması ile motive olabilmeli, çalışma azmi ve şevki kazandirılmalıdır (Arslan, 2012b: 251).

Özetle PTT A.Ş'de son dönem işletmecilik eksenli değişen kamu yönetimi ve iş anlayışı kurumda birtakım köklü değişiklikleri beraberinde getirmiştir. İnsani ve maddi bu problemlerin sayısı artmış ve şekli değişmiştir. Burada PTT A.Ş.'nin bir kamu kurumu olması 40 'dan fazla mevzuat çıktısı ile fonksiyonlarını yerine getirmesi onu özel sektör kurumlarından doğal olarak ayrıştırmaktadır. Yaşadığı çok değişik problemler karşısında bu problemlerin çözümünde PTT AŞ muadili herhangi bir kargo firmasında veya bankada olduğu gibi davranamayacaktır. Örneğin kârlılık adına çalışanlara, memurlara asgari ücret veremeyecektir (Acar, 2013: 199) Ama daha iyi hizmet vermek adına, iş tatmini ve örgütsel bağlılık konularında birtakım uygulamalar yapmak zorundadır. Bu açıdan PTT A.Ş.'de yaşanan yeni kamu yönetimi eksenli bu değişimin kurum çalışanlarını örgütsel bağlılık ve iş tatminlerinin ölçülmesi son derece önemlidir.

\section{Araştırmanın Amacı, Kapsamı ve Yöntemi}

Araştırmanın amacı; PTT'nin son dönemde yeni kamu yönetim anlayışı ile değişen yönetim yapısı, artan iş hacimleri ve örgüt yapısının değişmesi ile PTT A.Ş. çalışanlarının iş tatmini ile örgütsel bağlılık düzeylerini ölçmek ve çalışanların tatmin ve bağlılık düzeylerinin bazı demografik özelliklere göre farklılık gösterip göstermediğini incelemektir. Araştırmada, evren olarak 1-30 Kasım 2013 tarihleri arasında PTT A.Ş.'de çalışan tüm personel esas alınmıştır. Araştırma evrenini 40.000 PTT A.Ş. çalışanları oluşturmakta olup, örneklem olarak 442 kişiye ulaşılmıştır. Örneklemin seçilmesinde basit tesadüfi örnekleme yöntemi kullanılmıştır. Araştırma dönemi içerisinde 412 çalışanın anketleri bizzat anketörler tarafindan doldurulmuştur. Evren büyüklüğünden hareketle hata tolerans $1 \% 5$, güvenirlik düzeyi $\% 95$ alındığında 381 kişi yeterli olarak görülmektedir. Çalışma sonucunda 442 anket tam ve doğru olarak değerlendirmeye alınmıştır.

Ölçme aracı olarak araştırmacı tarafından geçerlilik ve güvenirliği sınanmış 'Minnesota İş Tatmini Ölçeği' ile Meyer ve Allen'in "Üç Boyutlu Örgüte Bağlllık Ölçeğì" kullanılmıştır. Minnesota İş Tatmini Ölçeği 5 'li likert tipinden oluşmakta ve her bir maddeye verilen cevaba göre

1 ile 5 arasında puanlandırılmaktadır. Meyer ve Allen'e ait örgütsel bağlılık ölçeği; duygusal bağlılık, devam bağlılığı ve normatif bağl1lık olmak üzere örgütsel bağl1lığı üç bileşen üzerinde incelemekte ve ölçek 5'li likert tipinden 
oluşmaktadır. Katılımcıların vermiş olduğu ifadelere göre maddeler 1 ile 5 arasında değerlendirilmektedir (Baysal ve Paksoy, 1999: 8).

Ölçeklerden oluşturulan anket formuna katılımcılara yönelik demografik değişkenler de eklenerek uygulama gerçekleştirilmiştir. Elde edilen veriler SPSS 23.0 paket programı kullanılarak frekans, korelasyon ve fark analizleri uygulanmıştır.

\section{Araştırmanın Bulguları}

Katılımcıların demografik özelliklerine ilişkin yaşı, cinsiyeti, eğitim durumu, hizmet süresi, medeni durumu ve çalışma şekline dair bulguları içermektedir. Katılımcıların demografik verilere göre frekans ve yüzdelikleri Tablo 1'de gösterilmiştir.

Tablo 1'den hareketle katılımc1ların 256's1 erkek 138'i kadındır. Çalışma en çok 112 kişi ile 28-35 yaş arası bireylerden oluştuğu görülmektedir. Katılımcıların eğitim durumu incelendiğinde ise 6's1 $(\% 1,40)$ ilköğretim, 86 's1

$(\% 19,50), 100$ 'ü $(\% 22,60), 196$ 's1 (\%44,3) lisans, 14'ü $(\% 3,20)$ lisansüstü mezunudur. Hizmet sürelerine bakıldığında özellikle son dönemdeki fazla alımlarla yeni işe başlayan sayısının fazlalığı $118(\% 26,70)$ kişi ile dikkat çekmektedir. 21 yıl üstü çalışan $118(\% 26,70)$ kişi ile deneyimli çalışan sayısının fazlalığı kurumun personel yapısı ile karşılaştırıldığında uyumludur. 286's1 $(\% 60,60)$ evli, 90’1 $(\% 20,40)$ bekar olan katılımcıların 138'i $(\% 31,20)$ kadrolu, 16 's1 $(\% 3,60)$ taşeron firma elemanı, 160'1 (\%36,20) sözleşmeli personeldir.

Katılımcıların duygusal, normatif ve devam bağlılığına ilişkin tanımlayıcı istatistikleri frekans, minimum-maksimum değeri, ortalama ve standart sapmaları Tablo $2^{\text {' }} \mathrm{de}$ gösterilmiştir.
Tablo 1: Demografik Veriler

\begin{tabular}{|c|c|c|c|}
\hline \multicolumn{4}{|c|}{ Demografik Veriler } \\
\hline \multirow[t]{5}{*}{ Cinsiyet } & & Frekans & Yüzde \\
\hline & Kadin & 138 & $31,20 \%$ \\
\hline & Erkek & 256 & $57,90 \%$ \\
\hline & Eksik Veri & 48 & $10,90 \%$ \\
\hline & Toplam & 442 & $100,00 \%$ \\
\hline \multirow[t]{8}{*}{ Yaş } & & Frekans & Yüzde \\
\hline & $20-27$ & 74 & $16,70 \%$ \\
\hline & $28-35$ & 112 & $25,30 \%$ \\
\hline & $36-43$ & 92 & $20,80 \%$ \\
\hline & $44-51$ & 100 & $22,60 \%$ \\
\hline & 51 üstü & 32 & $7,20 \%$ \\
\hline & Eksik Veri & 32 & $7,20 \%$ \\
\hline & Toplam & 442 & $100,00 \%$ \\
\hline \multirow[t]{8}{*}{ Eğitim } & & Frekans & Yüzde \\
\hline & İlköğretim & 6 & $1,40 \%$ \\
\hline & Orta öğretim & 86 & $19,50 \%$ \\
\hline & $\begin{array}{c}\text { Meslek } \\
\text { Yüksekokulu }\end{array}$ & 100 & $22,60 \%$ \\
\hline & Fakülte (lisans) & 196 & $44,30 \%$ \\
\hline & Lisansüstü & 14 & $3,20 \%$ \\
\hline & Eksik Veri & 40 & $9,00 \%$ \\
\hline & Toplam & 442 & $100,00 \%$ \\
\hline \multirow[t]{8}{*}{$\begin{array}{l}\text { Hizmet } \\
\text { Süresi }\end{array}$} & & Frekans & Yüzde \\
\hline & $1-5$ Y1l & 118 & $26,70 \%$ \\
\hline & 6-10 Y11 & 68 & $15,40 \%$ \\
\hline & $11-15$ Y1l & 56 & $12,70 \%$ \\
\hline & $16-20$ Yil & 60 & $13,60 \%$ \\
\hline & $21 Y_{11}$ Üstü & 118 & $26,70 \%$ \\
\hline & Eksik Veri & 11 & $5,00 \%$ \\
\hline & Toplam & 442 & $100,00 \%$ \\
\hline \multirow[t]{5}{*}{ Medeni Hal } & & Frekans & Yüzde \\
\hline & Evli & 268 & $60,60 \%$ \\
\hline & Bekar & 90 & $20,40 \%$ \\
\hline & Eksik Veri & 84 & $19,00 \%$ \\
\hline & Toplam & 442 & $100,00 \%$ \\
\hline \multirow[t]{6}{*}{ Çalıssma Şekli } & & Frekans & Yüzde \\
\hline & Kadrolu & 138 & $31,20 \%$ \\
\hline & $\begin{array}{l}\text { Taşeron Firma } \\
\text { Elemanı }\end{array}$ & 16 & $3,60 \%$ \\
\hline & Sözleșmeli & 160 & $36,20 \%$ \\
\hline & Eksik Veri & 128 & $29,00 \%$ \\
\hline & Toplam & 442 & $100,00 \%$ \\
\hline
\end{tabular}

Tablo 2: Duygusal, Normatif ve Devam Bağlılığına İlişkin Tanımlayıcı İstatistikler

\begin{tabular}{|c|c|c|c|c|c|}
\hline \multicolumn{6}{|l|}{ Duygusal, Normatif ve Devam Bağlılı̆ına İlişkin Tanımlayıcı İstatistikler } \\
\hline \multicolumn{6}{|l|}{ Duygusal Bağlılık } \\
\hline & $\mathrm{N}$ & Min. & Mak. & Ort. & Std. Sapma \\
\hline İş hayatımın geriye kalanını PTT de geçirmekten mutluluk duyarım & 434 & 1 & 5 & 3,16 & 1,509 \\
\hline İş yerinin problemlerini kendi problemlerim gibi hissediyorum & 430 & 1 & 5 & 3,56 & 1,326 \\
\hline $\mathrm{Bu}$ iş yerinde kendimi ailenin bir parçası gibi hissetmiyorum & 430 & 1 & 5 & 3 & 1,427 \\
\hline $\mathrm{Bu}$ iş yerine karşı duygusal bir bağ hissetmiyorum & 398 & 1 & 5 & 3,25 & 1,485 \\
\hline PTT benim için çok fazla kişisel anlam taşıyor özelleştirilse bile ayrılmam & 434 & 1 & 5 & 2,72 & 1,398 \\
\hline PTT ye güçlü bir aitlik duygusu hissetmiyorum özelleştirilebilir & 422 & 1 & 5 & 3,21 & 1,456 \\
\hline PTT'den ayrılma firsatım tereddüt etmeden başka bir işyerini tercih ederim & 434 & 1 & 5 & 3,05 & 1,507 \\
\hline Çalıştığım iş yerinden dışarıda gururla bahsediyorum & 414 & 1 & 5 & 3,44 & 1,341 \\
\hline \multicolumn{6}{|l|}{ Devam Bağlılığı } \\
\hline & $\mathrm{N}$ & Min. & Mak. & Ort. & Std. Sapma \\
\hline İstesem bile şu an iş yerimden ayrılmak benim için çok zor olurdu & 430 & 1 & 5 & 3,2 & 1,434 \\
\hline $\begin{array}{l}\text { Şu an iş yerinden ayrılmak istediğime karar verirsem hayatımın büyük bölümü } \\
\text { zarara uğrar }\end{array}$ & 442 & 1 & 5 & 3,12 & 1,406 \\
\hline Şu an iş yerinde kalmam bir istek olduğu kadar bir gereklilik & 426 & 1 & 5 & 3,61 & 1,294 \\
\hline $\begin{array}{l}\text { Bu iş yerinden ayrılmayı düşünmek için çok az seçim hakkına sahip olduğuma } \\
\text { inanıyorum }\end{array}$ & 430 & 1 & 5 & 3,42 & 1,356 \\
\hline $\begin{array}{l}\text { Benim için bu iş yerinden ayrılmanın olumsuz sonuçlarından biri de var olan } \\
\text { alternatiflerin azlığıdır }\end{array}$ & 442 & 1 & 5 & 3,43 & 1,311 \\
\hline $\begin{array}{l}\text { Başka bir iş ayarlamadan bu iş yerinden ayrıldığımda neler olacağı konusunda } \\
\text { endişe hissetmiyorum }\end{array}$ & 438 & 1 & 5 & 3,42 & 1,351 \\
\hline
\end{tabular}




\begin{tabular}{|c|c|c|c|c|c|}
\hline \multicolumn{6}{|l|}{ Normatif Bağlılık } \\
\hline & $\mathrm{N}$ & Min. & Mak. & Ort. & Std. Sapma \\
\hline $\begin{array}{l}\text { Bu iş yerinde çalışmaya devam etmemin önemli nedenlerinden biri, ayrılmamın } \\
\text { büyük kişisel fedakârlıklar gerektirmesidir. Başka bir iş yeri burada sahip olduğum } \\
\text { olanakları karşılamayabilir. }\end{array}$ & 438 & 1 & 5 & 3,24 & 1,402 \\
\hline Bu iş yerinde çalışmaya devam etmek için herhangi bir zorunluluk hissetmiyorum. & 430 & 1 & 5 & 2,67 & 1,405 \\
\hline Benim avantajıma olsa bile iş yerimden şimdi ayrılmak bana doğru gelmiyor & 426 & 1 & 5 & 3,26 & 1,431 \\
\hline İş yerimden şimdi ayrılsam suçluluk hissederim & 430 & 1 & 5 & 2,83 & 1,447 \\
\hline $\mathrm{Bu}$ iş yeri benim sadakatimi hak ediyor & 410 & 1 & 5 & 3,23 & 1,415 \\
\hline $\begin{array}{l}\text { Bu iş yerinden şimdi ayrılmanın orada çalışan diğer insanlara karşı duyduğum } \\
\text { sorumluluklar nedeniyle yanlış olacağını düşünüyorum. }\end{array}$ & 426 & 1 & 5 & 2,88 & 1,465 \\
\hline İş yerime çok şey borçluyum & 386 & 1 & 5 & 3,44 & 1,388 \\
\hline
\end{tabular}

Ölçeğin güvenilirliğini artırmak için bazı sorular tersten sorulmuştur. Analizlerde bu sorular puanlanırken tersten puanlanmıştır. Nihayetinde tüm ifadelerin analizlerinde 1 en olumsuz durumu gösterirken, 5 en olumlu durumu gösterir hale getirilmiştir. Duygusal Bağlllık ölçeğinde, katılımcıların en yüksek ortalaması "İş yerinin problemlerini kendi problemlerim gibi hissediyorum" ifadesinde $(3,56)$, en düşük ortalaması "PTT benim için çok fazla kişisel anlam taşıyor özelleştirilse bile ayrılmam” ifadesindedir $(2,72)$. Devam Bağlllığı ölçeğinde katılımcıların en yüksek ortalaması "Şu an iş yerinde kalmam bir istek olduğu kadar bir gereklilik" ifadesinde $(3,61)$, en düşük ortalaması "Şu an iş yerinden ayrılmak istediğime karar verirsem hayatımın büyük bölümü zarara uğrar" ifadesindedir $(3,12)$. Normatif Bağll1ık ölçeğinde, katılımcıların en yüksek ortalaması "İs yerime çok şey borçluyum" ifadesinde $(3,44)$, en düşük ortalaması " $\mathrm{Bu}$ iş yerinde çalışmaya devam etmek için herhangi bir zorunluluk hissetmiyorum." ifadesindedir $(2,67)$.

Katılımcıların iş tatminine ilişkin tanımlayıcı istatistikleri frekans, minimum-maksimum değeri, ortalama ve standart sapmaları Tablo 3 'te gösterilmiştir.

Tablo 3: İş Tatminine İlişkin Tanımlayıcı İstatistikler

\begin{tabular}{|c|c|c|c|c|c|}
\hline \multicolumn{6}{|l|}{ İş Tatmini } \\
\hline Yaptığım işten her zaman memnuniyet duyuyorum & $\mathrm{N}$ & Min. & Mak. & Ort. & Std. Sapma \\
\hline İ̧simde bağımsız çalışma imkânlarının olduğunu düşünüyorum & 414 & 1 & 5 & 3,46 & 1,413 \\
\hline İşimde arada sırada tekdüzelikten uzaklaşarak değişik şeyler yapma şansım oluyor & 418 & 1 & 5 & 2,83 & 1,425 \\
\hline İşimin toplum içerisinde 'saygın kişi' olma şansını bana verdiğini düşünüyorum. & 430 & 1 & 5 & 2,49 & 1,372 \\
\hline İş ortamındaki yöneticilerin yönetim tarzından memnunum & 430 & 1 & 5 & 3,11 & 1,5 \\
\hline Yöneticilerin karar verme yeteneklerini memnun edici buluyorum & 422 & 1 & 5 & 2,97 & 1,55 \\
\hline İş yerinde bana verilen sorumluluğu memnun edici buluyorum & 426 & 1 & 5 & 3,03 & 1,433 \\
\hline İşimi, bana garantili bir gelecek sağlaması bakımından yeterli buluyorum & 426 & 1 & 5 & 3,36 & 1,421 \\
\hline Yaptığım işi başkaları için bir şeyler yapabilme hissi açısından yeterli buluyorum & 422 & 1 & 5 & 3,47 & 1,308 \\
\hline Diğer çalışanların yönlendirilmesinde aldığım yetkiden memnunum & 430 & 1 & 5 & 3,37 & 1,26 \\
\hline Kendi bilgi ve yeteneklerime uygun bir iş yapmaktayım & 410 & 1 & 5 & 3,14 & 1,327 \\
\hline $\begin{array}{l}\text { İşle ilgili alınan kararların uygulamaya konması açısından işimi memnun edici } \\
\text { buluyorum }\end{array}$ & 422 & 1 & 5 & 3,2 & 1,454 \\
\hline Aldığım ücretin yaptığım işin karşıllı̆̆ olduğunu düşünüyorum & 418 & 1 & 5 & 3,03 & 1,351 \\
\hline İşimde ilerde terfi şans1 elde edeceğimi düşünüyorum & 418 & 1 & 5 & 3,02 & 1,426 \\
\hline Kendi fikir ve kanaatlerimi kullanabildiğim bir işte çalışmaktayım & 422 & 1 & 5 & 2,77 & 1,457 \\
\hline İşim bana kendi yöntemlerimi kullanma serbestliği tanıyor & 426 & 1 & 5 & 2,78 & 1,386 \\
\hline Çalışma şartları ve saatlerini uygun buluyorum & 418 & 1 & 5 & 2,65 & 1,474 \\
\hline İş ortamındaki arkadaşlık ilişkilerim işimden memnuniyet duymama katkı sağlar & 422 & 1 & 5 & 3,26 & 1,371 \\
\hline Yapılan işin takdiri açısından memnun edici olduğunu düşünüyorum & 426 & 1 & 5 & 3,75 & 1,331 \\
\hline Yaptığım işten her zaman memnuniyet duyuyorum & 422 & 1 & 5 & 3,18 & 1,439 \\
\hline
\end{tabular}

İş Tatmini ölçeğinde, katılımcıların en yüksek ortalamayı "Yapılan işin takdiri açısından memnun edici olduğunu düşünüyorum" ifadesi $(3,75)$, en düşük ortalamayı ise "İşimde arada sırada tekdüzelikten uzaklaşarak değişik şeyler yapma şansım oluyor" ifadesi $(2,49)$ oluşturmaktadır.

Yapılan çalışmada hem duygusal, normatif ve devam bağlılığına yönelik verilen cevaplarda hem de iş tatminine yönelik verilen cevaplarda, sonucun beklentilerin aksine pozitif yönde olduğu görülmüsştür.

Faktör Analizi, test oluşturmada ve test formlarından elde edilen puanların yorumlanmasında kullanılan bir istatistik yöntemidir. Yöntem, araştırmacının formu oluşturan testlerden alınan puanlar arasındaki korelasyonları açıklamak için gereken minimum belirleyici (faktör) sayısını hesaplamasına yarar (Arda vd., 2003:192). Bağlllık ölçeğinde faktör analizi gerçekleştirilmiş, öncelikle veri setinin faktör analizine uygun olup olmadığına bakılmıştır. Bağlılık ölçeğinde, tüm bileşenler dahil edildiğinde ortaya çıkan değerler faktör analizine uygun olmadığı için bazı sorular ölçekten çıkarılmıştır. Duygusal Bağlı̆lı ölçeğinden "İş hayatımın geriye kalanını PTT de geçirmekten mutluluk duyarım", "İş yerinin problemlerini kendi problemlerim gibi hissediyorum", "PTT benim için çok fazla kişisel anlam taşıyor özelleştirilse bile ayrılmam" ve "Çalıştı̆̆ım iş yerinden dışarıda gururla bahsediyorum" soruları analizden 
çıkarılmıştır. Devam Bağlılığ ölçeğinden ise; "İstesem bile şu an iş yerimden ayrılmak benim için çok zor olurdu" ve "Başka bir iş ayarlamadan bu iş yerinden ayrıldığımda neler olacağı konusunda endișe hissetmiyorum" soruları analizden çıkarılmıştır. Yine Normatif Bağl1lık ölçeğinde "Bu iş yerinde çalışmaya devam etmek için herhangi bir zorunluluk hissetmiyorum" sorusu analize dahil edilmemiştir.

Faktör analizine uygun olup olmadığı Kaiser-Meyer-Olkin (KMO) ve Barlett testi ile açıklanmaktadır. KMO ölçütü 0,9 ile 1 aralığında ise mükemmel, 0,8 ile 0,89 aralığında ise çok iyi, 0,7 ile 0,79 aralığında ise iyi, 0,6 ile 0,69 aralığında ise orta, 0,5 ile 0,59 aralığında ise zaylf ve son olarak 0,5 'in altında ise faktör analizi için yeterli olmamaktadır (Aydın, 2017: 4). Ölçeğe ilişkin KMO değeri 0,803 olarak elde edilmiştir. $\mathrm{Bu}$ sonuç veri setinin faktör analizine çok iyi derecede uygun olduğunu göstermektedir. Faktör analizi sonrasında ölçeklerin güvenilirlikleri test edilmiş ve güvenilirlik şartları sağlanırsa bundan sonraki analizlerde ölçek bileşenlerinin ortalamaları alınmıştır.

Güvenilirlik, bir testin iki yarımı yani o testin birbirine eş biçimleri üzerinden alınan puanlar arasındaki korelasyon katsayısıyla ya da aynı testin tekrar uygulanmasıyla ölçülür; yüksek korelasyon, test edilen popülasyon için alınan puanların tutarlılığının yüksek olduğunu göstermektedir (Arda vd., 2003: 242). Güvenilirlik testi için Cronbach's Alpha değeri kullanılmıştır. Cronbach's Alpha değerinin yorumlanması aşağıdaki tabloda özetlenmiştir.

Tablo 4: Ölçeklerin Güvenilirlik Testi

\begin{tabular}{|c|c|c|}
\hline \multicolumn{2}{|c|}{ Ölçeklerin Güvenilirlik Testi } & Cronbach's Alpha Değeri \\
\hline Boyut & Değişken Sayısı & $0,667^{*}$ \\
\hline Duygusal Bağlılık & 4 & $0,733^{*}$ \\
\hline Devam Bağlılı̆ı & 4 & $0,795^{*}$ \\
\hline Normatif Bağlılık & 6 & $0,935^{*}$ \\
\hline İș Tatmini & 19 & \\
\hline
\end{tabular}

$*>0,6$

Güvenirlik katsayısı (Cronbach's Alpha), duygusal bağlılık $(0,667)$, devam bağl1lığı $(0,733)$, normatif bağlılık $(0,795)$ ve iş tatmini $(0,935)$ üzerinde analiz edilmiştir. Güvenilirlik katsayısının 0,6'dan yüksek olması, bulguların yeterli güvenilirliğe sahip olduğunu göstermektedir (Şencan, 2005: 170). Buradan hareketle araştırmada kullanılan her iki ölçek ve alt boyutlarının güvenirlilik katsayısının yeterli güven düzeyinde olduğu kabul edilmiştir. Güvenirlilik analizi sonrasında ölçeklerin boyutlar arası korelasyon değerleri test edilmiş ve anlamsal ilişki araştırılmıştır.

$\mathrm{Bu}$ aşamada bağlılık boyutları ile iş tatmini arasında korelasyon olup olmadı $\breve{g} 1$ irdelenecektir. Korelasyon testi olarak Pearson korelasyonu kullanılmıştır. Bağlılık boyutları ile iş tatmini arasındaki korelasyon analizi yapılmadan önce değişkenlerin normal dağılım gösterip göstermediği incelenmiştir. Skewness ve Kurtosis değerleri $+1,5$ ila $-1,5$ arasında ise verilerin normal dağıldığ 1 söylenebilir (Tabachnick ve Field, 2013). Buradan hareketle her iki ölçeğin de normal dağılım gösterdiği ve parametrik olma şartını sağladığı kabul edilmiştir. Parametrik verilerin ölçümünde kullanılan Pearson test sonucuna göre iki ölçek ve alt boyutlarındaki korelasyon katsayısı Tablo 5'te gösterilmiştir.Tablo 5: Boyutlar Arası Korelasyon Değerleri

\begin{tabular}{|c|c|c|}
\hline \multicolumn{3}{|c|}{ Boyutlar Arası Korelasyon Değerleri } \\
\hline & & İş Tatmini \\
\hline \multirow{2}{*}{$\begin{array}{l}\text { Duygusal } \\
\text { Bağlılık }\end{array}$} & Pearson Korelasyonu & 0,232 \\
\hline & Örneklem & 218 \\
\hline \multirow{2}{*}{$\begin{array}{l}\text { Devam } \\
\text { Bağlılığı }\end{array}$} & Pearson Korelasyonu & 0,310 \\
\hline & Örneklem & 218 \\
\hline \multirow{2}{*}{$\begin{array}{l}\text { Normatif } \\
\text { Bağlılık }\end{array}$} & Pearson Korelasyonu & 0,648 \\
\hline & Örneklem & 218 \\
\hline
\end{tabular}

Gerçekleştirilen korelasyon testinde elde edilen sonuçların tamamı \%99 güven aralığında anlamlıdır $(\mathrm{p}<0,01)$. Yani bütün bağlılık boyutları ile iş tatmini arasında pozitif bir korelasyon söz konusudur. İş tatmini ile korelasyonun en yüksek olduğu bağlılık boyutu normatif bağl1lıktır $(\mathrm{r}=0,648)$. Buradan hareketle bireylerin iş tatminine ilişkin tutumlarının pozitif yönde artması durumunda normatif bağlılıklarının da oldukça yükseleceği söylenebilir. İkinci sırada ise devam bağlılığ boyutu gelmektedir $(r=0,310)$. Normatif bağlılık ile iş tatmini arasındaki ilişki kadar kuvvetli olmasa da yine iş tatminin artması durumunda bireylerin devam bağlılığının da pozitif yönde artış göstereceği söylenebilir. Diğer taraftan bireylerin duygusal bağlılığı ile iş tatmini arasında pozitif yönde anlamlı bir ilişkinin varlığından bahsetmek mümkündür (r=0,232). İş tatmininin tek boyut, bağlılığın üç boyutta incelendiği bu çalışmada bağlılık boyutlarının tamamının çalışanların iş tatminiyle anlamlı bir ilişki olduğu ortaya çıkmıştır. Buradan hareketle çalışanların iş tatmininin artması durumunda kuruma olan bağlılıklarının da artacağı, bağlılıkların azalması durumunda ise iş tatminin de azalacağ 1 görülmektedir.

Demografik verilere göre bağlılık ve iş tatmini boyutlarında verilen cevaplarda istatistiksel olarak anlamlı bir fark olup olmadığını test etmek için ANOVA testi kullanılmıştır. ANOVA'nın temel varsayımı olan varyansların homojenliğinin sağlanmadığı durumlarda ise ANOVA'nın non-parametrik karşılı̆̆ gerçekleştirilmiştir.

Her bir demografik değişken için ayrı ayrı fark analizi gerçekleştirilmiştir. Katılımcıların vermiş oldukları yanitlardan hareketle cinsiyet ve medeni hale göre fark analizi Tablo 6'da gösterilmiştir. 
O. K. Acar, Ç. Türkoğlu / KMÜ Sosyal ve Ekonomik Araştırmalar Dergisi 19 (33): 93-102, 2017

Tablo 6: Katılımcıların Cinsiyet ve Medeni Hale Göre Fark Analizi

\begin{tabular}{|c|c|c|c|c|c|c|c|c|c|c|c|}
\hline \multicolumn{5}{|c|}{ Cinsiyet } & & \multicolumn{5}{|c|}{ Medeni Hal } & \\
\hline & & $\mathrm{N}$ & Ortalama & $\begin{array}{l}\text { Std. } \\
\text { Sapma }\end{array}$ & $\begin{array}{l}\text { Test } \\
\text { Grubu } \\
\end{array}$ & & & $\mathrm{N}$ & Ortalama & $\begin{array}{l}\text { Std. } \\
\text { Sapma }\end{array}$ & $\begin{array}{l}\text { Test } \\
\text { Grubu } \\
\end{array}$ \\
\hline \multirow{2}{*}{$\begin{array}{l}\text { Duygusal } \\
\text { Bağlilık }\end{array}$} & Kadın & 136 & 3,15 & 1,07 & $\begin{array}{l}\text { Anova } \\
\text { Testi }\end{array}$ & \multirow{2}{*}{$\begin{array}{l}\text { Duygusal } \\
\text { Bağlılık }\end{array}$} & Evli & 268 & 3,17 & 1,07 & $\begin{array}{l}\text { Anova } \\
\text { Testi } \\
\end{array}$ \\
\hline & Toplam & 390 & 3,13 & 1,05 & 0,84 & & Toplam & 358 & 3,1 & 1,06 & 0,14 \\
\hline \multirow{3}{*}{$\begin{array}{l}\text { Devam } \\
\text { Bağlılığ1 }\end{array}$} & Kadın & 136 & 3,25 & 1,14 & \multirow{2}{*}{$\begin{array}{l}\text { Kruskal- } \\
\text { Wallis } \\
\text { Testi } \\
\end{array}$} & \multirow{3}{*}{$\begin{array}{l}\text { Devam } \\
\text { Bağlılığ1 }\end{array}$} & \begin{tabular}{|l} 
Evli \\
\end{tabular} & 268 & 3,36 & 0,98 & \multirow{2}{*}{$\begin{array}{l}\text { Kruskal- } \\
\text { Wallis } \\
\text { Testi } \\
\end{array}$} \\
\hline & Erkek & 254 & 3,41 & 0,93 & & & Bekar & 90 & 3,4 & 1,19 & \\
\hline & Toplam & 390 & 3,35 & $\mathbf{1 , 0 1}$ & 0,52 & & Toplam & 358 & 3,37 & 1,04 & $\begin{array}{r}0,60 \\
\end{array}$ \\
\hline \multirow{3}{*}{$\begin{array}{l}\text { Normatif } \\
\text { Bağlılık }\end{array}$} & Kadın & 136 & 3,16 & 1,01 & \multirow{2}{*}{$\begin{array}{l}\text { Anova } \\
\text { Testi } \\
\end{array}$} & \multirow{3}{*}{$\begin{array}{l}\text { Normatif } \\
\text { Bağlılik }\end{array}$} & Evli & 268 & 3,22 & 1,04 & \multirow{2}{*}{$\begin{array}{l}\text { Anova } \\
\text { Testi }\end{array}$} \\
\hline & Erkek & 254 & 3,14 & 1,08 & & & Bekar & 90 & 3,04 & 1,11 & \\
\hline & Toplam & 390 & 3,15 & 1,05 & 0,93 & & Toplam & 358 & 3,17 & 1,06 & 0,34 \\
\hline \multirow{3}{*}{ İş Tatmini } & Kadın & 133 & 3,17 & 0,98 & Anova & \multirow{3}{*}{ İş Tatmini } & Evli & 264 & 3,19 & 0,93 & \multirow{2}{*}{$\begin{array}{l}\text { Anova } \\
\text { Testi }\end{array}$} \\
\hline & Erkek & 251 & 3,11 & 0,93 & Testi & & Bekar & 90 & 3,17 & 0,95 & \\
\hline & Toplam & 384 & 3,13 & 0,94 & 0,66 & & Toplam & 354 & 3,18 & $\mathbf{0 , 9 3}$ & 0,92 \\
\hline
\end{tabular}

Cinsiyet ve medeni hale göre katılımcıların duygusal bağlılık, normatif bağlılık ve iş tatmini boyutlarında, varyanslar homojen dağılmaktadır $(\mathrm{p}>0,05)$. Bu boyutlarda Anova testi sonuçlarına bakılmıştır. Cinsiyete göre devam bağlılığı boyutunda ise varyanslar homojen olmadığ $(\mathrm{p}<0,05)$ için Anova'nın nonparamatrik karşılığı olan Kruskal-Wallis Testi'nin sonuçlarına bakılmıştır.

Anova testi neticesinde Duygusal Bağlılık, Normatif Bağlılık ve İş Tatmini boyutlarında cinsiyetler ve medeni haller arasında anlamlı bir fark yoktur $(p>0,05)$. Devam Bağlılığı için yapılan Kruskal-Wallis testine göre de devam bağlılığında cinsiyetler ve medeni haller arasında anlamlı bir fark yoktur $(\mathrm{p}>0,05)$.

Katılımcıların cinsiyet ve medeni hale göre duygusal bağlılık, devam bağlılı̆̆ı, normatif bağlılık ve iş tatmini arasındaki fark analizi Tablo 7'de gösterilmiştir.

Tablo 7: Katılımcıların Cinsiyet ve Medeni Hale Göre Fark Analizi

\begin{tabular}{|c|c|c|c|c|c|c|c|c|c|c|c|}
\hline \multicolumn{5}{|c|}{ Yaş } & & \multicolumn{5}{|c|}{ Eğitim } & \\
\hline & & $\mathrm{N}$ & Ortalama & $\begin{array}{l}\text { Std. } \\
\text { Sapma } \\
\end{array}$ & $\begin{array}{l}\text { Test } \\
\text { Grubu } \\
\end{array}$ & & & $\mathrm{N}$ & Ortalama & \begin{tabular}{|l|} 
Std. \\
Sapma \\
\end{tabular} & $\begin{array}{l}\text { Test } \\
\text { Grubu } \\
\end{array}$ \\
\hline \multirow{6}{*}{$\begin{array}{l}\text { Duygusal } \\
\text { Bağl1lik }\end{array}$} & $20-27$ & 74 & 2,77 & 1,02 & \multirow{6}{*}{$\begin{array}{l}\text { Anova } \\
\text { Testi }\end{array}$} & \multirow{6}{*}{$\begin{array}{l}\text { Duygusal } \\
\text { Bağglılık }\end{array}$} & Orta öğretim & 86 & 3,26 & \begin{tabular}{|l|}
1,06 \\
\end{tabular} & \multirow{6}{*}{$\begin{array}{l}\text { Anova } \\
\text { Testi }\end{array}$} \\
\hline & $28-35$ & 112 & 2,99 & 0,84 & & & $\begin{array}{l}\text { Meslek } \\
\text { Yüksekokulu }\end{array}$ & 100 & 3,33 & 0,86 & \\
\hline & $36-43$ & 92 & 3,23 & 1,09 & & & \begin{tabular}{|l} 
Fakülte(lisans) \\
\end{tabular} & 196 & 2,99 & 1,10 & \\
\hline & $44-51$ & 100 & 3,19 & 1,13 & & & Toplam & 402 & 3,13 & 1,03 & \\
\hline & 51 üstü & 32 & 3,71 & 0,99 & & & & & & & \\
\hline & Toplam & 410 & 3,11 & 1,04 & & & & & & & \\
\hline \multirow{6}{*}{$\begin{array}{l}\text { Devam } \\
\text { Bağlılığ1 }\end{array}$} & $20-27$ & 74 & 3,43 & 1,08 & \multirow{6}{*}{$\begin{array}{l}\text { Anova } \\
\text { Testi }\end{array}$} & \multirow{6}{*}{$\begin{array}{l}\text { Devam } \\
\text { Bağgl1lığ } 1\end{array}$} & Orta öğretim & 86 & 3,51 & 0,96 & \multirow{6}{*}{$\begin{array}{l}\text { Anova } \\
\text { Testi }\end{array}$} \\
\hline & $28-35$ & 112 & 3,29 & 0,99 & & & $\begin{array}{l}\text { Meslek } \\
\text { Yüksekokulu } \\
\end{array}$ & 100 & 3,38 & 1,06 & \\
\hline & $36-43$ & 92 & 3,39 & 0,91 & & & Fakülte(lisans) & 196 & 3,23 & 1,00 & \\
\hline & $44-51$ & 100 & 3,43 & 1,06 & & & Toplam & 402 & 3,37 & 1,01 & \\
\hline & 51 üstü & 32 & 3,21 & 1,12 & & & & & & & \\
\hline & Toplam & 410 & 3,37 & 1,01 & & & & & & & \\
\hline \multirow{6}{*}{$\begin{array}{l}\text { Normatif } \\
\text { Bağlll1k }\end{array}$} & $20-27$ & 74 & 2,77 & 1,13 & \multirow{6}{*}{$\begin{array}{l}\text { Anova } \\
\text { Testi }\end{array}$} & \multirow{6}{*}{$\begin{array}{l}\text { Normatif } \\
\text { Bağglilik }\end{array}$} & Orta öğretim & 86 & 3,43 & 1,03 & \multirow{6}{*}{$\begin{array}{l}\text { Anova } \\
\text { Testi }\end{array}$} \\
\hline & $28-35$ & 112 & 3,13 & 0,94 & & & \begin{tabular}{|l|} 
Meslek \\
Yüksekokulu \\
\end{tabular} & 100 & 3,08 & 1,04 & \\
\hline & $36-43$ & 492 & 3,22 & 1,18 & & & Fakülte(lisans) & 196 & 3,06 & 1,03 & \\
\hline & $44-51$ & 100 & 3,39 & 0,88 & & & Toplam & 402 & 3,15 & 1,04 & \\
\hline & 51 üstü & 32 & 3,51 & 0,96 & & & & & & & \\
\hline & Toplam & 410 & 3,18 & 1,04 & & & & & & & \\
\hline \multirow{6}{*}{ İş Tatmini } & $20-27$ & 74 & 3,11 & 0,88 & \multirow{6}{*}{$\begin{array}{l}\text { Anova } \\
\text { Testi }\end{array}$} & \multirow{6}{*}{ İş Tatmini } & Orta öğretim & 86 & 3,36 & 0,89 & \multirow{6}{*}{$\begin{array}{l}\text { Anova } \\
\text { Testi }\end{array}$} \\
\hline & $28-35$ & 112 & 2,93 & 0,99 & & & \begin{tabular}{|l} 
Meslek \\
Yüksekokulu \\
\end{tabular} & 98 & 3,21 & 0,94 & \\
\hline & $36-43$ & 90 & 3,08 & 0,97 & & & Fakülte (lisans) & 194 & 3,03 & 0,90 & \\
\hline & $44-51$ & 98 & 3,29 & 0,83 & & & Toplam & 398 & $\mathbf{3 , 1 4}$ & 0,91 & \\
\hline & 51 üstü & 32 & 3,61 & 0,67 & & & & & & & \\
\hline & Toplam & 406 & 3,13 & 0,92 & & & & & & & \\
\hline
\end{tabular}

Yaş ve eğitim düzeyine göre katılımcıların duygusal bağlılık, devam bağlılığı, normatif bağlılık ve iş tatmini boyutlarında varyanslar homojen dağılmaktadır $(\mathrm{p}>0,05)$. Bu boyutlarda Anova testi sonuçlarına bakılmıştır. Gerçekleştirilen Anova testi sonucunda \%95 güven aralığında devam bağlılı̆̆ ve iş tatmini boyutlarında yaş grupları 
arasında anlamlı bir fark yoktur ( $p>0,05)$. Duygusal bağlılık ve normatif bağlılık boyutlarında ise yaş grupları arasında anlamlı bir fark çıkmıştır. Varyansların homojen dağılmasından dolayı Post Hoc testlerinden olan Tukey testine bakılmıştır. Tukey testine göre " 51 üstü” yaş grubunun "20-27 yaş" grubuna göre duygusal bağlılığı daha yüksektir $(\mathrm{p}<0,05)$. Duygusal bağlılık boyutunda diğer gruplar arasında anlamlı bir fark yoktur ( $p>0,05)$. Yine Tukey testine göre "44-51 yaş" grubunun "20-27 yaş" grubuna göre normatif bağlılığı daha yüksektir $(\mathrm{p}<0,05)$. Normatif bağlılık boyutunda diğer gruplar arasında anlamlı bir fark yoktur.

Eğitim durumunda ise \%95 güven aralığında duygusal bağlılık, devam bağlılığı, normatif bağlılık ve iş tatmini boyutlarında gruplar arasında anlamlı bir fark yoktur $(\mathrm{p}>0,05)$.

Katılımcıların hizmet süresi ve çalışma şekline göre duygusal bağlılık, devam bağlılı̆̆ tatmini arasındaki fark analizi Tablo 8'de gösterilmiştir.

Tablo 8: Katılımcıların Hizmet Süresi ve Çalışma Şekline Göre Fark Analizi

\begin{tabular}{|c|c|c|c|c|c|c|c|c|c|c|c|}
\hline \multicolumn{5}{|c|}{ Hizmet Süresi } & & \multicolumn{5}{|c|}{ Çalışma Şekli } & \\
\hline & & $\mathrm{N}$ & Ortalama & $\begin{array}{l}\text { Std. } \\
\text { Sapma }\end{array}$ & $\begin{array}{l}\text { Test } \\
\text { Grubu }\end{array}$ & & $\begin{array}{l}\text { Çalışma } \\
\text { Şekli }\end{array}$ & $\mathrm{N}$ & Ortalama & $\begin{array}{l}\text { Standart } \\
\text { Sapma }\end{array}$ & $\begin{array}{c}\text { Test } \\
\text { Grubu }\end{array}$ \\
\hline \multirow{6}{*}{$\begin{array}{l}\text { Duygusal } \\
\text { Bağl1l1k }\end{array}$} & $1-5$ Yil & 118 & 2,85 & 0,90 & \multirow{5}{*}{$\begin{array}{l}\text { Anova } \\
\text { Testi }\end{array}$} & \multirow{6}{*}{$\begin{array}{l}\text { Duygusal } \\
\text { Bağl1l1k }\end{array}$} & Kadrolu & 138 & 3,33 & 0,89 & \multirow{5}{*}{$\begin{array}{l}\text { Bağımsız } \\
\text { Örneklem } \\
\text { T testi }\end{array}$} \\
\hline & 6-10 Y1l & 68 & 3,11 & 1,06 & & & Sözleşmeli & 160 & 2,96 & 1,11 & \\
\hline & 11-15 Y1l & 56 & 3,11 & 1,08 & & & Toplam & 298 & 3,15 & 1,00 & \\
\hline & 16-20 Y1l & 60 & 2,98 & 1,06 & & & & & & & \\
\hline & 21 Y11 Üstü & 118 & 3,45 & 1,07 & & & & & & & \\
\hline & Toplam & 420 & 3,11 & 1,04 & $\mathrm{p}=0,03$ & & & & & & $\mathrm{t}=2,20$ \\
\hline \multirow{6}{*}{$\begin{array}{l}\text { Devam } \\
\text { Bağll1lı̆g1 }\end{array}$} & $1-5 Y_{11}$ & 118 & 3,29 & 1,10 & \multirow{5}{*}{$\begin{array}{l}\text { Kruskal- } \\
\text { Wallis } \\
\text { Testi }\end{array}$} & \multirow{6}{*}{$\begin{array}{l}\text { Devam } \\
\text { Bağl1lı̆̆1 }\end{array}$} & Kadrolu & 138 & 3,66 & 0,81 & \multirow{5}{*}{$\begin{array}{l}\text { Mann- } \\
\text { Whitney } \\
\text { U Testi }\end{array}$} \\
\hline & 6-10 Y11 & 68 & 3,52 & 0,83 & & & Sözleşmeli & 160 & 3,19 & 1,08 & \\
\hline & 11-15 Y11 & 56 & 3,54 & 0,82 & & & Toplam & 298 & 3,42 & 0,95 & \\
\hline & 16-20 Y11 & 60 & 3,00 & 1,13 & & & & & & & \\
\hline & 21 Y11 Üstü & 118 & 3,45 & 0,99 & & & & & & & \\
\hline & Toplam & 420 & 3,36 & 1,00 & $\mathrm{p}=0,38$ & & & & & & $z=-2,56$ \\
\hline \multirow{6}{*}{$\begin{array}{l}\text { Normatif } \\
\text { Bağlılık }\end{array}$} & 1-5 Y1l & 118 & 2,73 & 0,96 & \multirow{5}{*}{$\begin{array}{l}\text { Anova } \\
\text { Testi }\end{array}$} & \multirow{6}{*}{$\begin{array}{l}\text { Normatif } \\
\text { Bağl1lik }\end{array}$} & Kadrolu & 138 & 3,45 & 0,88 & \multirow{5}{*}{$\begin{array}{l}\text { Mann- } \\
\text { Whitney } \\
\text { U Testi }\end{array}$} \\
\hline & 6-10 Y1l & 68 & 3,35 & 1,13 & & & Sözleşmeli & 160 & 2,86 & 1,13 & \\
\hline & 11-15 Y1l & 56 & 3,29 & 1,15 & & & Toplam & 298 & 3,15 & 1,01 & \\
\hline & 16-20 Y11 & 60 & 3,01 & 1,00 & & & & & & & \\
\hline & 21 Y11 Üstü & 118 & 3,47 & 0,92 & & & & & & & \\
\hline & Toplam & 420 & 3,15 & 1,04 & $\mathrm{p}=0,00$ & & & & & & $\mathrm{z}=-3,247$ \\
\hline \multirow{6}{*}{$\begin{array}{c}\text { İş } \\
\text { Tatmini }\end{array}$} & \begin{tabular}{|l|}
$1-5 \mathrm{Y}_{1} \mathrm{l}$ \\
\end{tabular} & 118 & 3,01 & 0,81 & \multirow{5}{*}{$\begin{array}{l}\text { Anova } \\
\text { Testi }\end{array}$} & \multirow{6}{*}{$\begin{array}{c}\text { İş } \\
\text { Tatmini }\end{array}$} & Kadrolu & 138 & 3,39 & 0,91 & \multirow{5}{*}{$\begin{array}{l}\text { Bağımsız } \\
\text { Örneklem } \\
\text { T testi }\end{array}$} \\
\hline & 6-10 Y11 & 68 & 3,18 & 1,10 & & & Sözleşmeli & 158 & 2,82 & 0,88 & \\
\hline & 11-15 Y1l & 54 & 3,02 & 1,00 & & & Toplam & 296 & 3,10 & 0,90 & \\
\hline & 16-20 Y1l & 60 & 3,03 & 1,03 & & & & & & & \\
\hline & 21 Y11 Üstü & 116 & 3,32 & 0,83 & & & & & & & \\
\hline & Toplam & 416 & 3,13 & $\mathbf{0 , 9 3}$ & $\mathrm{p}=0,35$ & & & & & & $t=3,85$ \\
\hline
\end{tabular}

Hizmet süresine göre katılımcıların duygusal bağlılık, normatif bağlılık ve iş tatmini boyutlarında varyanslar homojen dağılmaktadır ( $\mathrm{p}>0,05)$. Bu boyutlarda Anova testi sonuçlarına bakılmıştır. Hizmet süresine göre devam bağlılığı boyutunda ise varyanslar homojen olmadığ $1(p<0,05)$ için Anova'nın nonparamatrik karşılığı olan Kruskal-Wallis Testi'nin sonuçlarına bakılmıştır.

Gerçekleştirilen Anova testi sonucunda \%95 güven aralığında iş tatmini boyutunda, hizmet sürelerine göre gruplar arasında anlamlı bir fark yoktur $(\mathrm{p}>0,05)$. Duygusal bağlılık boyutunda, hizmet sürelerine göre gruplar arasında anlamlı bir fark çıkmıştır $(\mathrm{p}<0,05)$. Varyansların homojen dağılmasından dolayı Post Hoc Testlerinden olan Tukey testine bakılmıştır. Tukey testine göre "21 yıl üstü" hizmet süresine sahip olanların "1-5 yıl" hizmet süresine sahip olanlara göre duygusal bağlılığı daha yüksektir. Diğer gruplar arasında \%95 güven aralığında anlamlı bir fark yoktur. Anova testi neticesinde \%99 güven aralığında normatif bağl1lık boyutunda hizmet sürelerine göre gruplar arasında da anlamlı bir fark çıkmıştır $(\mathrm{p}<0,05)$. Yine varyansların homojen dağılmasından dolayı Post Hoc Testlerinden olan Tukey testine bakılmıştır. "6-10 y1l" hizmet süresine sahip olanlar ve "21 y1l üstü" hizmet süresine sahip olanların "1-5 yıl” hizmet süresine sahip olanlara göre normatif bağlılığı daha yüksektir. Diğer gruplar arasında \%95 güven aralığında anlamlı bir fark yoktur $(\mathrm{p}>0,05)$. Devam bağlılığı için yapılan Ki-Kare KruskalWallis testine göre \% 95 güven aralığında devam bağlılığı boyutunda hizmet sürelerine göre gruplar arasında anlamlı bir fark yoktur $(\mathrm{p}>0,05)$.

Çalışma şekline göre yapılan fark analizinde ise, çalışmaya dahil olan Taşeron Firma Elemanı sayısı 16 ile sınırlı kalmıştır. Dolayısıyla fark analizlerinde değerlendirmeye alınmamıştır. Bağlılık bileşenleri ve iş tatmini açısından kadrolu elemanlar ile sözleşmeli elemanlar arasında istatistiksel olarak anlamlı bir fark olup olmadığ incelenmiştir. Varyansların homojenliği şartı, duygusal bağımlılık ve iş tatmini ölçeklerinde sağlanmış olup fark analizi t testi ile gerçekleştirilmiştir.

Gerçekleştirilen $\mathrm{t}$ testi sonucunda \%95 güven aralığında Duygusal Bağlılık açısından kadrolu personel ile sözleşmeli personel arasında anlamlı bir fark çıkmıştır $(\mathrm{t}=2,204)$. Kadrolu personelin duygusal bağlılığı daha yüksektir. İş tatmini açısından da benzer bir tablo söz konusudur. \%95 güven aralığında kadrolu personel ile sözleşmeli personel arasında anlamlı bir fark vardır $(\mathrm{t}=3,851)$. Kadrolu personelin iş tatmin düzeyi daha yüksektir. Varyansların homojenliği şartının sağlanmadığı devam bağlılığı ve normatif bağlılık 
ölçeklerinde fark analizleri nonparametrik test olan MannWhitney $U$ testi ile gerçekleştirilmiştir. Gerçekleştirilen Mann-Whitney U testi sonucuna göre \%95 güven aralığında kadrolu personel ile devam bağlılığı arasında anlamlı bir fark vardır $(\mathrm{z}=-2,56)$. Kadrolu personelin devam bağlılı̆̆ daha yüksektir. Normatif bağlılık sonuçları da benzerlik göstermektedir. Kadrolu personel ile normatif bağlllık arasında anlamlı bir fark vardır $(\mathrm{z}=-3,247)$. Kadrolu personelin normatif bağlılı̆̆ daha yüksektir.

\section{Sonuç}

PTT A.Ş.'de son dönemde yeni kamu yönetim anlayışı ile birlikte işletmecilik eksenli olarak değişen yönetim yapısı, artan iş hacimleri ve örgüt yapısının değişmesi ile PTT A.Ş. çalışanlarının örgütsel bağlılık ve iş tatmin düzeylerinin düşeceği hipotezi ile yapılan bu çalışmada örgütsel bağlılık ve iş tatminine yönelik verilen cevapların beklentilerin aksine pozitif yönde olduğu görülmüş, bütün bağlılık boyutları ile iş tatmini arasında pozitif yönde anlamlı bir ilişki olduğu sonucuna ulaşılmıştır. Buradan hareketle PTT A.Ş. çalışanlarının örgütsel bağlılıklarının artması, iş tatmini düzeyini de pozitif yönde artıracaktır. Özellikle son yıllarda kamu yönetiminde işletmecilik eksenli yaşanan değişimin somut çıktılarına PTT A.Ş. üzerinden bakıldığında; PTT A.Ş.'nin iş hacminin arttığı, yapısı ve uygulamalarının değiştiği görülmektedir. $\mathrm{Bu}$ değişim sonucunda kamu çalışanlarında işletmecilik eksenli iş tatmini ve bağlılık konularında bir düşüş beklenirken çalışma sonucunda böyle bir veriye ulaşılamamıştır. Bu noktada geleneksel kamu yönetimine yönelik olarak yapılan hantallaşma, verimsizlik, vb. eleştirilerin haklılığının ortaya çıktığı söylenebilir.

Çalışma ile gerçekleştirilen fark analizleri sonucunda, belirli gruplar arasında istatistiksel anlamda farklılıklar çıkmıştır. Buna göre "51 üstü” yaş grubunun "20-27 yaş" grubuna göre duygusal bağlılığının, yine "44-51 yaş" grubunun "20-27 yaş" grubuna göre normatif bağlılığının daha yüksek olduğu sonucuna ulaşılmıştır. "21 yıl üstü” hizmet süresine sahip olanların "1-5 yıl" hizmet süresine sahip olanlara göre duygusal bağlılığının da daha yüksek olduğu görülmektedir. Son olarak kadrolu personelin iş tatmini düzeyi, normatif bağl1lık ve devam bağlılığı sözleşmeli personele göre daha yüksektir. Bu noktada çıkan sonuçlar, özellikle genç çalışanların desteklenmesi gerektiği yönünde yorumlanabilir.

Örgütsel bağlılık ve iş tatminin zayıfladığı noktada yapılması gereken sadece çalışanların somut iş çıktılarından ziyade, yaratıcı fikir ve eylemlerinin desteklenmesi, işlerini anlamlı ve önemli buldukları, özgür oldukları, fikirlerinin objektif değerlendirildiği ve farkına varıldığı, yönetimin kontrolcü olmak yerine destekleyici olduğu bir örgüt ikliminin iş tatminini artıracağı ve çalışanların işten ayrılma niyetinin azalacağı görülmektedir (Çekmecelioğlu, 2005: 32)

\section{Kaynaklar}

Acar, O. K., Yeni Kamu Yönetimi Paradigma Çerçevesinde Bir Örnek Olay Olarak 2000 Sonrası Posta Telgraf (PTT A.Ş.) Teşkilatı Ve Hizmetleri, Süleyman Demirel Üniversitesi Sosyal Bilimler Enstitüsü Kamu Yönetimi Anabilim Dalı, Yayınlanmamış Doktor Tezi.

Allen, N. and Meyer, J. (1990). The Measurement And Antecedents Of Affective, Continuance And Normative
Commitment To The Organization. Journal Of Occupational Psychology, Vol. 63.

Arda, E., Kılıçgedik, N., Bakan, S., Bakan, İ., Kemer B., Sosyal Bilimler El Sözlüğü, Alfa Yayıncılık, İstanbul, 2013.

Arslan, A., "Beşeri-Sosyal Sermayenin Uygun Kullanımının Kurumsal Verimliliğe Ve Performansa Etkisi: Sakarya Ptt Başmüdürlüğü Çalışanları İle Uygulamalı Bir Çalışma", Akademik İncelemeler Dergisi, Cilt 7, Sayı 1 Ss. 227-253, 2012.

Aşan, Ö. ve Erenler, E., (2008) "İş Tatmini Ve Yaşam Tatmini İlişkisi”, Süleyman Demirel Üniversitesi İktisadi Ve İdari Bilimler Fakültesi Dergisi, C.13, S.2 S.203216.

Aydın, A. H., Türk Kamu Yönetimi, Sistemi Niteliği, Örgütü, Sorunları, Seçkin Yayıncılık, Ankara, 2011.

Aydın, Berna Z., (2007), "Faktör Analizi Yardımıyla Performans Ölçütlerinin Boyutlarının Ortaya Konulması”, 8. Türkiye Ekonometri Ve İstatistik Kongresi, İnönü

Üniversitesi, Malatya.

Bayram, L., (2005) "Yönetimde Yeni Bir Paradigma: Örgütsel Bağlılık”, Sayıştay Dergisi, Sayı: 59, Ss125-139

Baysal, A. C., Paksoy, M. (1999). Mesleğe ve örgüte bağlılığın çok yönlü incelenmesinde Meyer-Allen örgütsel bağlılık ölçeği. İ.Ü.İşletme Fakültesi Dergisi , 28, 7-15

Bilgiç, V., "Yeni Kamu Yönetimi Anlayışı", Ed. Asım Balcı Vd., Kamu Yönetiminde Çağdaş Yaklaşımlar, Seçkin Yayınevi, Ankara, Ss. 25-38, 2003.

Çekmecelioğlu, H., "İş Tatmini Ve Örgütsel Bağlılık Tutumlarının İşten Ayrılma Niyeti Ve Verimlilik Üzerindeki Etkilerinin Değerlendirilmesi: Bir Araştırma", "İş,Güç" Endüstri İlişkileri Ve İnsan Kaynakları Dergisi Cilt:8 Sayı:2, Ss, $153-168$

Çekmecelioğlu, H., G., (2005). “Örgüt İkliminin İş Tatmini Ve İşten Ayrılma Niyeti Üzerindeki Etkisi: Bir Araştırma" C.Ü. İktisadi Ve İdari Bilimler Dergisi, Cilt 6, Sayı 2, Ss, 39-23.

Çiçek, A. C., (2012), "Neo Liberalizmin "Yeni Kamu Yönetimi” Anlayışını Meşrulaştırma Aracı Olarak 'Yönetim' Ve Türkiye Kamu Yönetimi Üzerine Yansımaları", Ed. Y. Koçak A.C. Çiçek, Kamu Yönetimi Yönetim Ve Siyaset Ekseninde Yeniden Yapılanma, Gazi Kitapevi, Ankara, Ss. 62-70.

Duman, G., (200) “ Yönetim Açısından İş Tatmini”, Anadolu Üniversitesi Sosyal Bilimler Enstitüsü,

Yayınlanmamış Yüksek Lisans Tezi, Eskişehir.

Durna, U., Eren, V., (2005) "Üç Bağlılık Unsuru Ekseninde Örgütsel Bağlılık” Doğuş Üniversitesi

Dergisi, 6 (2) Ss, 210-219

Emhan, A., Gök, R., (2011), "Bankacıl1k Sektöründe Personel Memnuniyeti Ve Örgütsel Bağlılık

Arasındaki İliksilerin Araştırılması Muhasebe Ve Finansman Dergisi, Ss, 157- 174

Erdem, R. (2007), “Örgüt Kültürü Tipleri İle Örgütsel Bağlılık Arasındaki İlişki: Elazı̆̆ İl Merkezindeki Hastaneler Üzerindeki Bir Çalışma”, Eskişehir Osmangazi Üniversitesi İ̈BF Dergisi, Ss, 63-79

Gül, H., Oktay, E., Gökçe, H., (2008) "İş Tatmini, Stres, Örgütsel Bağlılık, İşten, Ayrılma Niyeti Ve Performans Arasındaki İlişkiler: Sağlık Sektöründe Bir Uygulama" Akademik Bakış, Uluslararası Hakemli Sosyal Bilimler EDergisi, Sayı 15 
Karataş, S.,Güleş, H., (2010) “İlköğretim Okulu Öğretmenlerinin İş Tatmini İle Örgütsel Bağlılığı Arasındaki İlişki”, Uşak Üniversitesi Sosyal Bilimler Dergisi $3 / 2, \quad$ Ss, 74-89

Kök, B., S., (2006) "İş Tatmini Ve Örgütsel Bağlılı̆̆ın İncelenmesine Yönelik Bir Araştırma”, Atatürk Üniversitesi İktisadi Ve İdari Bilimler Dergisi, Cilt: 20, Say1: 1, 291-317

Lamba, M., (2014), "Yeni Kamu Yönetimi Perspektifinden Türkiye'de Kamu Yönetimi Reformları: Genel Gerekçeler Üzerinden Bir İnceleme", Süleyman Demirel Üniversitesi İktisadi Ve İdari Bilimler Fakültesi Dergisi, C.19, S.3, Ss. 135152.

Meyer, J. And Allen,N.(1991). A Three-Component Conceptualization Of Organizational Commitment. Human Resource Menagement Review, Vol. 1-1.

Morhead, G., Griffin, R.W. (1996). Organizational Behavior Managing People And Organizations, Five Edition, Houghton Mifflin Comp. Boston.

Ömürgönülşen, U., “Kamu Sektörünün Yönetimi Sorununa Yeni Bir Yaklaşım: Yeni Kamu Kamu İşletmeciliği”, Ed. Muhittin Acar Ve Hüseyin Özgür, Çağdaş Kamu Yönetimi-1, Nobel Yayın Dağıtım, Ankara, Ss. 3-43, 2003

Ömürgönülşen, Uğur (1997), “ The New Puplic Menagement”, Aüsbf Dergisi, 52: 517- 516.

Örücü, E., Kılıç, R. Ve Şimşir, S. (2010) "Organizasyonlarda İş Tatmini Uygulamaları ve Örgütsel Bağlılığa Etkisi Üzerine Bir Araştırma. Balıkesir Üniversitesi, Bandırma İ.İ.B.F Yönetim Ve Ekonomi Araştırmaları Dergisi, Cilt: 13 Sayı: 1.

Örücü, E., Yumuşak S., Bozkır, Y., (2006) "Bankalarda Çalışan Personelin İş Tatmin $\quad$ Ve İş Tatminini Etkileyen Faktörlerin İncelenmesine Yönelik Bir Araştırma" Celal Bayar Üniversitesi İ.B.B.F. Yönetim Ve Ekonomi Dergisi, Cilt:13, Say1:1.

Poyraz, K., Kama, B., (2008), “Algılanan İş Güvencesinin İş Tatmini, Örgütsel Bağlılık ve İşten Ayrılma Niyeti Üzerindeki Etkilerinin İncelenmesi”, Süleyman Demirel Üniversitesi İktisadi Ve İdari Bilimler Fakültesi Dergisi, C.13, S.2 S.143-164

PTT, (2012), Dünyada Ve Türkiye'de Posta Hizmetlerini İlişkin Sektör Raporu 2011, Ankara.

PTT, (2013), Dünyada Ve Türkiye'de Posta Hizmetlerini İlişkin Sektör Raporu 2012, Ankara.
Schermerhorn, J.R, J. G. Hunt, R. N. Osborn (1994) Managing Organizational Bahaior, Eighth Edition, McgrawHill Book Co., Newyork .

Swailes, S., (2002). "Organizational Commitment: A Critique Of The Construct And Mearues" International Journal Of Menagement Reviews, Vol. 4, Iss. 2, 155-178.

Şencan, H., (2005), " Sosyal Ve Davranışsal Ölçümlerde Güvenilirlik Ve Geçerlilik”, Seçkin Yayıncılık, Ankara, 2005.

Tabachnick, G.B., Fidell,S.L., "Using Muhtivariate Statistics (6th Ed.)", Pearson Education, England, 2013.

Tengilimoğulu, D. (2005) "Hizmet İşletmelerinde Liderlik Davranışları İle İş Doyumu Arasındaki İlişkinin Belirlenmesine Yönelik Bir Araştırma", Ticaret Ve Turizm Eğitim Fakültesi Dergisi, 1(24): 23-45.

Toker, B., (2007), 'Demografik Değişkenlerin İş Tatminine Etkileri: İzmir'deki Beş Ve Dört Yıldızlı Otellere Yönelik Bir Uygulama”, Doğuş Üniversitesi Dergisi, 8 (1) Ss, 92-107

Ugboro, I., Obeng, K., 2000, “Top Menagement Leadership, Employee Emporwe Job Satisfaction, And Customer Satisfaction İn Total Qality Menagement Organizations: An Empirical Study", Jounal Of Quatily Menagement, 5 (2), Pp.247/272

Üstüner, Y., "Kamu Yönetim Kuramı Ve Kamu İşletmeciliği Okulu”, Amme İdaresi Dergisi, Cilt 33, Sayı 3, Ss. 15-31, 2000

Yıldırım, H., Vd., (2011), "Yüzme Hakemlerinde Örgütsel Bağlılık İle İş Tatmini Arasındaki İlişkinin Kanonik Korelasyon Analizi İle İncelenmesi”, Zkü Sosyal Bilimler Dergisi Cilt 7, Say1 13, 2011, Ss. 163-186 